\title{
S2 - Remoción de arsénico en agua de consumo humano mediante la técnica de coagulación-floculación
}

\author{
Andrés Araya-Obando ${ }^{1 *}$, Johnny Valverde-Cerdas ${ }^{2}$, Paola Rojas-Chaves ${ }^{2}$, Luis G. Romero-Esquivel ${ }^{2}$ \\ ${ }^{1}$ Escuela de Ingeniería en Construcción y ${ }^{2}$ Escuela de Química, Instituto Tecnológico de Costa Rica.
}

*Autor al que se dirige la correspondencia: jobando@tec.ac.cr

\section{Resumen}

$\mathrm{E}^{1}$ n Costa Rica, se han identificado aguas de consumo humano con concentraciones de arsénico mayores al límite permitido $(10 \mu \mathrm{g} / \mathrm{L})$. En este sentido, la tecnología de coagulación/floculación puede ser potencialmente utilizada como una alternativa de tratamiento. La presente investigación evaluó la eficiencia del cloruro de hierro (III) junto con la adición de dos floculantes, uno sintético (polímero catiónico KF-930-S) y otro natural (mozote Triumfetta semitriloba Jacq, Malvaceae). Se hicieron ensayos de jarras utilizando una concentración de arsénico de $200 \mu \mathrm{g} / \mathrm{L}$. Las condiciones óptimas fueron $\mathrm{pH}$ 6, dosis de cloruro de hierro (III) de $12 \mathrm{mg} / \mathrm{L} \mathrm{y} 14 \mathrm{mg} / \mathrm{L}$ para el polímero catiónico $(1 \mathrm{mg} / \mathrm{L})$ y el mozote $(250 \mathrm{mg} / \mathrm{L})$, respectivamente. Como mecanismos de separación, se utilizó filtración rápida con arena $(0.5 \mathrm{~mm})$. Se definieron tiempos de floculación de $1 \mathrm{~min}$ en ambos casos. Se obtuvieron eficiencias de remoción cercanas al 96\%, obteniendo concentraciones de arsénico en el efluente menores a $10 \mu \mathrm{g} / \mathrm{L}$. Los análisis de potencial Z, mostraron que el floc formado, está cargado positivamente al utilizar agua sin iones y cargada negativamente al usar agua sintética con iones interferentes. Posiblemente, el mecanismo de remoción, al usar agua sin iones interferentes, se debe a la atracción electrostática del arsenato (adsorción). Al contrario, en presencia de iones interferentes, probablemente los iones de adsorbato se enlazan directamente a la superficie del material por medio de la formación de complejos de esfera interna.

Palabras claves: Remoción de arsénico, cloruro de hierro (III), polímero catiónico, floculantes naturales, potencial Z.

\begin{abstract}
$\mathrm{I}^{\mathrm{n}}$ Costa Rica, water for human consumption with arsenic concentrations above the permissible limit $(10 \mu \mathrm{g} / \mathrm{L})$ have been identified. In this sense, the technology of coagulation/flocculation can be potentially used as an alternative of treatment. The present research evaluated the efficiency of iron chloride (III) together with the addition of two flocculants, one synthetic (polymer cation KF-930-S) and other natural (mozote Triumfetta semitriloba Jacq, Malvaceae). Pitchers trials using an arsenic concentration of $200 \mu \mathrm{g} / \mathrm{L}$ were made. Optimal conditions were $\mathrm{pH} 6$, doses of iron chloride (III) of $12 \mathrm{mg} / \mathrm{L}$ and $14 \mathrm{mg} / \mathrm{L}$ for the polymer cation $(1 \mathrm{mg} / \mathrm{L})$ and the mozote $(250$ $\mathrm{mg} / \mathrm{L})$, respectively. Quick filtration with sand $(0.5 \mathrm{~mm})$ was used as separation mechanisms. Flocculation times of 1 min were defined in both cases. Removal efficiencies close to $96 \%$, obtaining less than $10 \mu \mathrm{g} / \mathrm{L}$ concentrations of arsenic in the effluent were obtained. The analysis of potential $\mathrm{Z}$, showed that the floc formed, is positively charged when water without ions is used, and negatively charged when synthetic water with interfering ions is used. Possibly, the removal mechanism, when using water without interfering ions, is the electrostatic attraction of arsenate (adsorption). On the contrary, in the presence of interfering ions, probably adsorbate ions are bound directly to the surface of the material through the formation of inner sphere complexes.
\end{abstract}

Keywords: Arsenic removal, iron chloride (III), cationic polymer, natural flocculants, potential Z sobre protección a los derechos de autor, con criterio especificados en la licencia Creative Commons (CC BY-NC-SA 4.0) 